\title{
Poverty-alleviation communication practices of the Jerusalem Children and Community Development Organization (JeCCDO) in Negede Woito community, Bahir Dar, Ethiopia
}

Negesse Belay Gessese (iD ${ }^{1 凶}$

\begin{abstract}
Poverty is an important issue for third world Sub-Saharan African countries such as Ethiopia. To assist with poverty alleviation, a great number of nongovernmental organizations have moved resources into the region, but the problem has not significantly improved. This paper studies the Jerusalem Children and Community Development Organization (JeCCDO), an NGO that has engaged in poverty alleviation programs in Ethiopia for more than 35 years. The study examines communication practices used by JeCCDO as part of its poverty alleviation programs in Negede Woito community (Bahir Dar, Ethiopia). We use a qualitative research methodology to assess the organization's communication practices, as well as the challenges it and the Negede Woito community face. Poverty is perceived as lack of resources by JeCCDO, but the community also prioritizes other forms of poverty such as psychological and cultural. Our findings reveal that JeCCDO is renowned for using a social enterprise development model and a participatory communication approach. However, in practice we find these are not used. In the models, endogenous knowledge and grassroots communication were vital to community development, but JeCCDO did not implement them during planning, implementing, and evaluating community-based programs. Community workers who coordinated the organization and the community were Negede Woito community members. Besides grassroots communication, knowing the context and living situation of the community is mandatory for development agents. JeCCDO did not contextualize development efforts, such as sheep fattening and poultry for people who did not have shelter. In conclusion, we propose that nongovernmental organizations and development workers should reconsider their communication contexts and practices while launching new poverty alleviation programs.
\end{abstract}




\section{Introduction}

- he article explores non-governmental organizations (NGOs) poverty alleviation communication practice for sustainable development in sub-Saharan Africa specifically in Ethiopia. It has a long history of poverty alleviation programs in the region, but it lacks sustainability. One of the prominent factors has been poor communication practice. In this article, we investigate one of the NGOs-Jerusalem Community Children Development Organization (JeCCDO) which has been working for more than 35 years in Ethiopia. We found that the organization contributed a lot to the community financially, yet their problem has not been solved as expected.

Background of the study. It is widely expected that NGOs can reach and improve the wellbeing of the poor who are the subject of NGO assistance. NGOs have played a noticeable role in the development sector since 1970s in Africa. They broadly praised for their assets as innovative and grassroots driven organizations. They have had the aspiration and ability to follow participatory and people-centered forms of development to fill gaps left by the failure of states across the third world in meeting the needs of their poorest citizens. The world has seen an increase in the number of NGOs dealing with matters of development to reduce poverty, while it remains uncertain as to why after many years of NGOs operation, poverty is still a problem. It becomes imperative to study the communication component in NGOs' poverty relief programs. Notably, NGOs operate across the world with noticeable activities in the developing nations to alleviate poverty.

After half a century of implementing development programs, over a billion people in the third world still live on less than one US dollar a day at the end of the 20th century. More than two billion people who are one-third of the global population do not have access to potable clean water. Hundreds of millions of people lack adequate health care or basic educational opportunities. Overall, the global development picture is still very miserable, regarded as rising global poverty and polarizing inequality, especially in Sub-Saharan including Ethiopia and many developing countries (Jeff, 2011).

The use of communication as a vehicle of development activities have been hailed, alluded in several international organizations summits (FAO, 2010). Communication is crucial to the success of development activities in third world countries. NGOs presumed to have crucial roles of change agencies to relieve nations and communities faced with various challenges. Among these encounters poverty has been a key.

World poverty and its alleviation have been both local and global issues confronting the governments of the world today. The extent of the challenge mandates all governments, NGOs as well as faith institutions to put their hands on area to tackle the danger.

Ethiopia had been one of the highest poverty rates in the world in 2000 , with $56 \%$ of the population living on $<\$ 1.25$ purchasing power parity (PPP) a day (Hill and Tsehaye, 2014). Ethiopians experienced a decade of astonishing progress in wellbeing and by the start of this decade $<30 \%$ of the population was counted as poor (Hill and Tsehaye, 2014). For this success, agricultural growth drove to decline in poverty. It has been supported by propoor spending on basic services, and rural safety nets. Structural change has been remarkably absent from the Ethiopia story of progress although there is some indication of manufacturing growth beginning to reduce poverty in urban areas. Many people inquired to know what will be needed to end poverty in Ethiopia. Besides, the current successful way of agricultural progress and pro-poor spending, the role of the non-farm rural sector, such as, internal displacement and urban poverty reduction should have been given due attention.

The problem. Poverty is not an easy concept to define; hence, a variety of definitions exist. The definitions are influenced by diverse ideologies and disciplinary approaches. The dominant one since World War II has been in economic terms, using levels of income (Grusky and Kanbur, 2006) and defining the poor by a head count of those who fall below a given income (Lipton and Ravallion, 1993).

Presently, development efforts have started with emphasis on important factors, such as human capacity and access to relevant information and facilities. Recognized practices from the field of development have indicated it tends to fail for two basic reasons (Mefalopolus, 2008). These are lack of participation and unsuccessful communication.

Participatory communication ascertains cheering participation, motivating rational thought, and underlining procedure, rather than particular results related to the administration style and programs of majority NGOs (Altafin, 1991). He clarifies involvement dares to be exist on all platforms of development schemes. Target societies ought to be exhilarated to take part in from planning to evaluation of the implemented tasks. This might give NGOs interest in its and communities lives, and offer the communities with the wisdom of possession and abilities. These could give NGOs to perform beyond the development plans. Community liberation from different forms of poverty has been achieved through participatory models to development communication (Altafin, 1991). He adds that empowerment can be achieved and sustained as long as the target community judgmentally reflect their lived experiences and realize the causes for success and failure of intrusions.

Brown (1985) posits that succeed poverty reduction efforts must bring together the change agents and the intended beneficiaries in a joint inquiry to understand their contextual realities, identify needs and implement development. This means that participatory approaches can offer a promising tool for promoting people-centered development in social, political, and economic systems which boost local empowerment. Lack of participation among target groups or community members in either the planning, implementation or decision-making process of development initiatives is one of the key reasons for the letdowns of some programs (Chambers, 1997; cited in Mefalopulos, 2008).

For Sub-Saharan Africa, poverty is dynamic and fleeting, resulting in different sectors and groups of the population moving in and out of poverty over time. The United Nations adopted the goal to get rid of extreme poverty and had planned between 1990 and 2015 in which the proportion of people whose income is less than one US dollar a day. Handley et al. (2009) argue while efforts are made to decrease poverty in Sub-Saharan Africa, there are factors that carry on hindering that attainment.

The Sub-Saharan African countries, like, Ethiopia have inadequate finances and are riddled by poor supremacy, ethnic violence, and corruption has failed to lead to development for all of their citizens. In Ethiopia, NGOs have been advocated since the 1980s due to famine and drought as a means to bridge between citizens' needs and existing services. To this end, JeCCDO was established in 1985 to tackle the very serious drought in Ethiopia. During that time, many people lost their lives. JeCCDO started as a humanitarian organization, in response to the necessities of children who were displaced, orphaned, or lacked proper care and support due to man-made and natural disaster since then. 
This study was conducted to explore JeCCDO's use of communication in community based development programs in Negede Woito community Bahir Dar.

\section{Research questions.}

1. What did Negede Woito community need and JeCCDO's poverty reduction practice?

2. Did Negede Woito community participate JeCCDO's project planning, implementing, monitoring, and evaluation?

3. How did JeCCDO's project accommodate indigenous knowledge as a point of reference for enhanced understanding of the community desires?

4. Which factors did affect Negede Woito community from development?

The objective of the study was to explore JeCCDO's project communication effectiveness in alleviating poverty from Negede Woito Community in Bahir Dar.

\section{Theoretical framework and review of related literature}

Literature review gives the researcher insight into what has already been done in the selected field, pinpointing its strengths and weaknesses Kombo (2006). Understanding the previous inquiry helps the researcher to ascertain a significant problem which will provide new understanding in the area under study.

Theoretical framework. Participatory communication theory was used as a theoretical framework.

Participatory communication. The term participatory communication comes from community development. It denotes the theory and practices of communication used to encourage people to participate from planning to the decision-making process of development (Mefalopulos, 2008). He clarifies the main purpose of communication ought to be communal to all the participants. This embraces the sharing of meanings, perceptions, or familiarity of stakeholders who involved in a development project. That mean community could be benefiting from development projects equitably. The main features that portray participatory communication are associated with its capacity to involve the human issues of social change in the process of interconnecting through communication (Gumucio Dagron, 2001).

In compiling stories of social transformation, GumucioDagron notes that participatory approaches targets to put decision-making in the peoples' hands. He elucidates that engaging participatory approach builds up the competence of communities to provoke their ideas towards development plans with planners working for aid organizations. Moreover, participatory approach builds up an internal democratic manner in which all members have their own role within the communities.

Among the protagonists of the participatory approach, Beltrán (2004) describes the modernization paradigm has been promoting a top-down, ethnocentric and patriarchal view of development. He distinguished interposition which was focused on messages to better reach individuals, or behavioral change was unable to appliance social change. Gumucio Dagron (2001) claims that communication in participatory principle offers a sense of self to the local community that obtains aid; particularly, in communities who have been demoted, suppressed or ignored for years. Employing participatory communication approach helps to put in cultural pride and self-esteem between the indigenous people. It also supports indigenous forms of organization, and keeps custom and values by easing the assimilation of new elements. Therefore, it has been relevant to this study to apprehend how Negede Woito community felt about participating in JeCCDO community development programs to alleviate poverty.

Additional role of participatory communication is that it decides whether the communication practice is modified to every community members in terms of content, language, culture, and medium, rather than the predisposition to use the similar communication strategies in various cultural sceneries, and for diverse social segments of society (Gumucio Dagron, 2001). Development communication necessitates compassion between cultural multiplicity and particular contexts were ignored. $\mathrm{He}$ summarizes that lack of compassions responsible for the letdowns of many transnational development ventures.

Gumucio-Dagron et al. claim development communication requests to be human focused, to use communication as a tool, to include the community and to warrant the success of projects. These approaches show that involving community members in the deeds of an NGO might help to make sure their complete involvement and support of the projects are anticipated for their advantage. This kind of circumstance might support NGOs to empower the community and to take control of the developments.

In accentuating the importance of media in communication, participatory concepts offered a new understanding of development communication, and extended the idea of participation further than what was reflected in the modernization theories. Melkote (1991) favors locals are preferred to agency experts to public participation. Participatory theoreticians believe that homegrown knowledge as disparate to expert and external knowledge as supreme to the success of development projects (Melkote, 1991; Gumucio Dagron, 2001; Altafin, 1991).

Participatory communication helps to identify the belief and felt needs of local people, and the donors thought about the people have to have (Gumucio Dagron, 2001). He elucidates community-based conversation and dialogical communication help to identify and distinguish between people need and donordriven communication need. Brett (1993) ratifies that publics ought to be seen as associates and not aid receivers. $\mathrm{He}$ exemplifies that currently several health and social problems are ill-suited to the top down approaches to health intervention. Brett adds the attainment of projects lies in the talent and commitment of NGOs to keep a connection to every participant.

Non-governmental organization's role in community development programs. It was ostensible failures of state-led development approaches during the 1970s and 1980s that drove interest in NGOs as a development alternative. During that time, it was offering innovative and human centered approaches to service delivery, advocacy and empowerment. As NGOs and their position within the development sector have raised vibrantly though the taxonomy of NGOs remains problematic (Vakil, 1997). Commonly, NGO's have two roles in the development process, as service suppliers and promoters for the poor. They offer a broad spectrum of services across multiple fields, ranging from livelihood interventions, education and health service to more specific areas, like, democracy building, human rights, emergency response, conflict resolution, finance, environmental management, policy analysis, etc. (Lewis and Kanji, 2009) for the overall community development.

Community development is a way of producing individual empowerment toward the collective control and responsibility for community wide needs. Workers take a partnership approach to assist a community's capacity to decide and address its own needs, goals, and the way out to its problems (Mendes and Binns, 2013). Community development increases community participation, community empowerment, deployment and integration of 
resources, mutual control and responsibility, autonomy, access and equity, developed corporation, communal wellbeing, and collective righteousness.

Development communication practice in local NGOs. Early concerns in the prospective consumption of mass communication to transfer information were valuable to develop communication. It depicted the courtesy of a number of communication scholars. Among these leading scholars to the diffusion of innovations were Everett Rogers (1962) and his associates. Modernization concepts were obsessed by behaviorist, positivist, and empiricist suppositions, Beltrán (2004). These particular predispositions accounted for why organizational issues were overlooked and why interventions were focused on behavior changes at the individual level instead of addressing social grounds of scarcity and downgrading.

Later, other theorizers criticized diffusion of innovation as a modernist approach. Development challenges stemmed from the uneven sharing of properties created by the international extension of Western capitalism (Servaes, 1996). Servaes also describes dependency analysis was informed by Marxist and critical theories which mention the problems of the poor countries imitate the general underlying forces of industrial development.

After modernization, Dependency approach advocates philosophers, like, Hornik (1988) argues the problems of underdevelopment were not inside to poor African countries but were dogged by outside factors. For instance, previous colonies were assimilated into the world economy. Hornik clarified that the problems of the third world countries were political than the deficiency of information. Boafo (1995) encompasses this argument and articulates that underdevelopment in the SubSaharan African countries stemmed from economic factors, like, leading place in western held universal order. He elucidates the North such; for instance, USA and EU nations have had the authority to make political verdicts for the poorest countries, like Ethiopia. Westerns have been leading the Sub-Saharan poor countries to become dependent on economic, political, and ideological by means of aid. Hence, the powerful ones might govern the powerless in every context, in communication too.

One of the participatory theorists, Gumucio Dagron (2001), describes that from powerful to the powerless communication approach of inducement models covertly undertakes the knowledge of regimes and organizations has been right. However, local populations have been leveled as either they did not know, or had inappropriate beliefs about the development. The powerful ones are heard and can persuade the powerless. In this context, government and donors are powerful whereas the communities become voiceless. He addresses that since development plans were coming from outside villages, societies did not feel belongings. Gumucio-Dagron also clarifies the sense of disempowerment was also rooted because communities did not have the choice to throw away blessings or announce amendments to involvements. He adds that development communication needs thoughtfulness to cultural multiplicity and context-specific programs. He privileges absence of such sensitivity accounts for the difficulties and failures of several transnational development projects. Consequently, participatory theorists modified development communication definition as it is the efficient utilization of channels of communication to enhance community involvement in development project programs. It also helps to tell, inspire, and train people at the grassroots and existing life experience. Participatory theorists believe that development communication wanted to be human centered instead of media-centered.

Among development communication scholars, Melkote (1991) defines communication as a process of generating and thought- provoking understanding as the foundation for development than diffusion of information. He elaborates communication ought to comprise the articulation of social relations amid the people. Melkote explicates people ought not to be obligatory to implement new practices whatever valuable they are in the appreciations of donors and governments. Instead, publics need to be cheered to involve than embrace new practices based on information. This hinders people creativity to find solution for their own local problems. Adoption lacks context. One project may be valid in a context but not all. In underlining the importance of media in communication, participatory theorists delivered a new understanding of development communication, and stretched out the notion of participation broader than the principles of modernization. Melkote argues citizens are crucial to public participation instead of donor agency officials. Participatory theoreticians restrain expert's role and outside knowledge by underlining the criticality of local knowledge and ambitions in development.

White (1994) argues that participatory communication inspires involvement, critical thinking, and underscoring process and advancement as everyday jobs of development communication. White expounds involvement needs to be existent in all phases of development ventures. Communities ought to be fortified to take part from planning to evaluation of implemented programs. This might give them a feeling of involvement in the development deeds within their communities, and offer them with a feeling of proprietorship of development projects instigated.

Participatory communication principles gave evidence that mainly contributes to develop communication. For this reason, empowerment can be achieved as long as community members critically reveal on their capabilities and realize the causes for letdowns and achievements of programs. In short, participatory paradigm is a repeatedly used term meant to describe family of approaches; however, I would prefer to refer to this approach as the dialog paradigm, as suggested by Guba (1990) because conversation is at the core of participation, communication and even empowerment (Freire, 2005).

\section{Research method and design}

Research method. This study employed qualitative research which gives an in-depth understanding of the human world through studying people's know-hows, world views, societal as well as material life (Snape and Spencer, 2003 cited in Ali, 2017). The method made possible to establish the types of development, NGOs have accomplished and to clarify why such development practice is commenced.

The study took an exploration one particular JeCCDO's community project. The unit is JeCCDO, an Israeli-based NGO. Case study approach allowed the researcher to investigate existing system over time through meticulous data from documents, face to face interviews and focused group discussions (FGD) acquired from the participants and contextual information gained from the website and annual reports about the program, the aims, visions, and mission of JeCCDO (Creswell, 2013; Charmaz, 2006).

Research setting. Ethiopia, which is the second largest populace in Africa, is one of the poorest and least human development indexes countries in the world. The country has nine regional states and two administrative cities. Among nine regional states, Amhara, which is found in North West of Ethiopia is the second populist in the country. Its capital is Bahir Dar which most Negede Woito community destines. Negede Woito community is among the minority ethnic groups who live in and round Bahir Dar. 
In Ethiopia, it has been the tenacity of famine and drought for the last four decades (Ali, 2017). To tackle this challenge, a number of humanitarian organizations have flooded into the country, but the problem persists. According to JeCCDO 2015 annual report JeCCDO is among the humanitarian actors, and it was established in 1985 as an indigenous, charitable organization in response to the needs of children who were orphaned and evacuated due to civil war and famine in the country. Since then, the organization has comprehensive about 850,000 recipients per year. The organization has three main programs. The first is Access to Basic Services for Orphans and Helpless Children, the second program is Community-Based Disaster Risk Reduction and the third is Capacity Development of Community-Based Organizations (CBOs). JeCCDO's vision is to see an Ethiopian people where all citizens endorse the wellbeing of children. Its mission is to assist community development processes where the welfare of children is successfully supported in all its target areas. Its development approach has been child centered, family focused and community based. JeCCDO's core values are to inspire community participation in child-centered development, to be responsible and apparent to patrons to esteem community values, to make certain sustainability of development outcomes and to team up with others to promote the welfare of children. The organization runs in Bahir Dar and Debre Birhan from Amhara region, Debrezeit from Oromiya region, Dire Dawa from selfadministered city, and Hawassa (South Nations Nationalities Peoples Republic). This study was delimited to its study area only Bahir Dar, Negede Woito destination, and from the JeCCDO programs, Capacity Development of CommunityBased Organization.

Participants and sampling. The kind of the research sampling technique was purposive. The sample elements were picked owing to their specific features which ease in-depth investigation and empathetic of the fundamental concerns of the research. The samples which were categorized into three groups were community development workers (staff members of JeCCDO), the Negede Woito community and the organization's documents (JeCCDO website and annual reports).

From Negede Woito community, five of them were selected by available sampling and participated in FGD and four JeCCDO staffs have been purposely selected and interviewed. The participants were coordinated by a retired JeCCDO staff, aged 68, and became JeCCDO's community development worker for 25 years. The man helped the researcher to access Negede Woito community and community development workers and developed a sense of trust to conduct the interviews and focus group discussion (FGD). The FGDs and interviews were recorded with a cell phone. The recorded data were transcribed verbatim and categorized into thematic groups. All participants spoke Amharic; hence, the transcribed data were translated into English.

Data collection tools. Based on the theoretical orientation of participatory communication for development, Ali (2017) using qualitative tools (such as FGDs, interviews, and documents) might help a researcher understands deep-rooted problems and suggests some sort of solution. More specifically, this research employed qualitative tools so as to cognize the use of participatory communication mainly in confronting underdevelopment problems; to know how communication, development, and participation have been perceived by public development workers and community and to elucidate the factors which shape the communication rehearses and effects on development.
Interview. In depth interview was used to know more on the practice of communication in development programs to discover the experiences of participants and development efforts, as well as to describe the practices of participatory communication. Ritchie and Lewis argue that "very complex systems, processes or experiences are generally best addressed in in-depth interviews because of the depth of focus and the opportunity for clarification and detailed understanding" (2003, p. 59). The interview lasted 45-60 min for every participant.

Focus group discussion. FGD was employed within the local community who are the stakeholders of the organization in so as to recognize their participation in the development efforts made by JeCCDO. Obeng-Quaidoo (1986) cited in Ali (2017) states group discussion in the African context enables to approach the non-individuality of the African culture in their usual setting. Similarly, Ritchie and Lewis (2003) put up with that FGD also offer a social circumstance that the phenomenon is experienced, and they parade the context can form people's views by presenting how data are produced through conversation with others.

The scholars further contend that FGD is suitable for realizing abstract and elusive issues, like, poverty, development, and participation (Ritchie and Lewis, 2003). Meanwhile, the FGD took an hour and forty minutes.

Document analysis. The attention of using document analysis was receiving organization's documents, such as communication works, strategic and yearly plans and project schemes, and annual reports. These documents were collected by the organization centered on their manner for the study. Analyzing such documents, the researcher realizes the communication and development process implemented by JeCCDO. For example, the documents might tell us if and how participatory development is deliberated by this organization. Analyzing the content of documents might also help find key strategies used to organize community members as well as communication activities of the organization (Ali, 2017). This document analysis enables me to understand the overall tendencies of their development communication practices. Moreover, this tool is used to endorse the research findings obtained by other data-gathering tools, like interviews and FGDs. Therefore, JeCCDO website and annual reports were analyzed.

Data analysis. The data were analyzed thematically. Themes were emerged based on research questions and conceptual over view of related literature. Consequently, a total of four themes were emerged.

\section{Finding and discussion}

The findings and discussions of this study were presented in the thematic groups. Research questions and the review of related literature strengthen to emerge the research themes that include the community need, development, homegrown knowledge, communication systems, community participation, and factors affecting development. These major themes were found in the review of related literature and explored in the data to answer the research questions. In addition, a new theme was formed out of the data. This was particularly cultural practices and impact of political context which enhances persistence of poverty in the community owing to the disregarding of communication.

Question one dealt with what Negede Woito community felt needs and JeCCDO development practices. To find out this, I relied on JeCCDO's website, annual report and FGD with the community. Communication for development is a participatory and organized procedure of designing the best approach and 
chains of actions by which a communication process will realize the proposed objectives. It involves establishing a conversation and rallying the proposed patrons to decide suitable communication outputs according to their characteristics, desires, capabilities, and resources (FAO, 2010). The FGD discussants stated that their interest is lack of residence, education center, training, Shower and Toilet based on priority order; however, JeCCDO's project built Shower and public water pipe first. The project designed short-term training about saving, hand crafts, mobile maintenance, Bajaj driving license training, Sewing, etc. After the training, the project did not see the trainees back. One of the discussants claimed that the project lacks monitoring and evaluation, rather simply donating, not solving the problem permanently.

The discussants added that their prior problem in life is lack of permanent house, feeling of insecurity and discrimination. However, JeCCDO's project helped them by constructing public service, like, pipe water, shower, toilet and income generating building. Although the project helped a lot, they preferred residence, security and free from oppression first. They claimed that if the organization asked them about their problem, their priority choice would be different. Communication for development conglomerates a variety of participatory methods and communication tools to address the knowledge and information needs of participants. It also facilitates their active involvement in development initiatives. Participant commitment is required at every stage of the community development process. To this end, field workers and community leaders heighten their skills in designing and applying participatory communication strategies and services; particularly, to face new pressing problems in the community. However, it is inferred that JeCCDO did not employ participatory communication during planning stage.

Presently, development efforts have begun to focus important issues, like, human capacity, access to information, knowledge and services. Acknowledged practices have indicated development inclines to fail for two basic reasons (Mefalopolus, 2008). These are absence of participation and unsuccessful communication.

The website and annual report documents showed that the vision of JeCCDO is "Envisages to see Ethiopia where no child lives in poverty" and its mission is "Advance the care and protection of children within the family and the community for their all rounded development". Nevertheless, Negede Woito community is oppressed psychologically due to discrimination. The project strives to make the community, equip financially. JeCCDO's strategic goals are enlightening access and worth of social services to children and helpless community members; firming up the livelihoods of exposed children in their community; making a systematized move towards social businesses as a sustainable development model; evolving the structural and economic capacity of community-based organizations, and strengthening social, entrepreneurial, and institutional capacity of JeCCDO. For attaining their goals, the project built an income generating building, and tried the community children to go to 'Kulkual Meda' primary school. The discussants stated that since the community is considered as naughty their children are considered as not disciplinary too. Still, their community name - 'Woito' is considered as an insult, but the fact is for naming only.

Brown (1985) posits that succeed poverty reduction efforts must bring together the change agents and the intended beneficiaries in a joint inquiry to understand their contextual realities, identify needs and implement development. This means that participatory approaches can offer a promising tool for encouraging people-centered development in political and economic systems that boost local empowerment. Lack of participation among target groups from planning to evaluation process of development initiatives is one of the main reasons for the letdowns of some programs (Chambers, 1997; cited in Mefalopulos, 2008).

According to JeCCDO annual report (2015) JeCCDO considers children grow best in their families and communities. Hence, JeCCDO follows child centered, family focused, and communitybased development approach. JeCCDO has worked to bring positive changes and influence on the welfare of children through conglomerate with community-based organizations. The discussants acknowledged that the JeCCDO contributed a lot to the community though still they have a number of problems which they face.

Social enterprise development model intends that social enterprises are longstanding agents of comprehensive growth and have proved irrepressible in the face of economic adversity. By design, social enterprises address socioeconomic challenges in innovative ways and engage citizens to become part of the solution. This inferred that the Negede Woito Community should take part in to solve their problem from need analysis to the evaluation process. On the other hand, the project planned and implemented to help this community by donating resources. As the discussants mentioned, they received help from JeCCDO without their saying and participation.

One of JeCCDO's major intermediaries in the Negede Woito community focused on stimulating the culture of hygiene and the providing of clean water. The Negede Woito elder community did not even have access to formal education before, but now a library has been constructed at 'Kulkual Meda' primary school to enhance the quality of education for their children, since JeCCDOs mission is to facilitate community development process where the contented state of being happy, healthy, and prosperous of children is effectively promoted in all target areas. However, the discussants mentioned that the other community children and teachers underestimated Negede Woito children. The respondents preferred not to send their children to school due to undermine. The community women did not have any information about saving. They started their weekly meetings, on which they discuss pertinent issues, celebrate community successes, and share agonies, were also introduced by JeCCDO. This is one of the successes of JeCCDO in the community. The practice of open excretion has stopped since community members have got latrines now. Moreover, one of the interviewees said, "We were nothing more than the residents of Bahir Dar; there was no change in our lives before JeCCDO". So, the project helped a lot whatsoever there was a mismatch between the felt needs.

The second question revealed whether JeCCDO project accommodate local knowledge and context for better development and fill the needs of the community. To get informed, I relied on interviews the JeCCDO staff and community FGD. The data indicated that JeCCDO intended to help the community by introducing new technology instead of promoting and adding value to the local crafts.

According to Mefalopulos and Tufte (2009) participatory communication is not just the exchange of information and experiences, but it is also the investigation and the generation of new knowledge intended at addressing circumstances that need to be amended.

One of the projects program was to promote urban agriculture and small livestock husbandry to the targeted community. For this program, most communities' small livestock husbandry is part and parcel of the livelihood particularly for poor household. On the top of this, the component was intended to help poor households produce protein-rich food items. Accordingly, backyard poultry keeping, sheep fattening, and improvement of smallscale dairy production were implemented. 
Similarly, the discussants mentioned that the urban agriculture and small livestock husbandry were given to Negede Woito community. Paradoxically, people without residence where poultry keeping and goat fattening have taken place. For this reason, some of the community members immediately sold the poultry and goat before keeping and fattening. Others lost due to death. The program was good, but lacks context.

For JeCCDO's basic needs project, development means economic empowerment. I asked the community members whose shower, building, and water they were. They all replied, "The shower, the building and water pipes are JeCCDO's". This inferred that the community lacks belongings. I raised the same questions to the community development workers. Community workers replied the same as the community. Interviewee one added that the project left its hand, and fully owned by the community. JeCCDO ensures social enterprise development model to mobilize more resources from local sources, which would help to respond sustainably to current and emerging development defies.

Communication for development combines numerous communication roles (Acunzo, 2009): ascertaining indigenous knowledge, needs, anticipations, and supremacies; assisting justifiable access to relevant information and knowledge; solidification peoples' capacity to make their voices heard; fostering multistakeholder dialog and decision-making processes; endorsing participation and collective action; increasing shared learning and co-creation of knowledge; refining concession, coordination, and interacting. Although there were a number of construction workers in the Negede Woito communities, the income generating building for the community was built by other (out of Negede Woito community) daily labor workers. The project did not exploit local knowledge; hence, lack of coordination means, lack of participatory communication.

Indigenous knowledge is crucial for participation, for people make decisions based on their existing experience and knowledge (Sackey, 2014). Sackey adds that development activities which impose an outside technology without considering the local people need cannot be participative. Indigenous knowledge and the idea of sustainability are also interwoven. JeCCDO's community development workers are the member of the society. The community women are popular in handcrafts, such as 'moseb, sefed...' These crafts have been means of income earning for many Negede Woito communities. The project trained 50 community women have modern sewing and decorated treading-'tilf sira'-but none of them is working now. And more than 50 youths were trained in mobile and electronics maintain, yet no one is working after training. The only sustaining one is the indigenous practice of the community. That is 'dengel' hand crafts of 'moseb' and 'sefed'. Often it is the indigenous practice that is sustainable while many modern technologies harm the environment or force local people onto an economic routine.

Question three was raised to investigate Negede Woito community's participation during different phases of implementing community development programs which were launched for them. For this reason, I collected data through FGD and the data revealed that Negede Woito community had limited participation during planning, implementing, monitoring, and evaluation of JeCCDO's projects. Everything was done on in one way, top down communication approach.

The data showed that Negede Woito community members do not involve into JeCCDO planning and decision-making. These impacts the communication systems the JeCCDO practices in implementing the community-based programs. The organization believes that consulting the Negede Woito community opinion leaders is taken as they are involved in the development programs from planning to evaluation process the project. However, the
Negede Woito community who took part during FGD said that JeCCDO community workers told them about development programs, but they did not participate in deciding in any level of the project, rather it was one way. They explained that they did not participate directly with donors of the JeCCDO and did not contribute their suggestions about the program.

During the World Congress on Communication for Development in (2006) Communication for development has been defined as it is a social process based on a conversation using a wide array of methods and tools. It is looking for change at diverse intensities, listening, building faith, sharing information and skills, debating, building policies, and learning for continued and significant change. To the contrary, the finding showed that the JeCCDO's project planned to build ground plus one building having 10 classes some years ago. The building was income generating for the community. The project coordinator agreed to a building construction project contract financially and started clearing the place for use. At the site, it was planned to begin construction the next day. Unfortunately, all the contractors did were left empty during the night. The next morning, the contractor and the project coordinator reported to the police and police investigated the action was done by the Negede Woito community members. Police officers told to JeCCDO's project worker, "Why did you suffer to such community if they were not willing to have?" Finally, the planned project failed with anger. The JeCCDO staff did not ask the community why it happened. After 3 years, the building was built for the community in other places of the same Kebele. The community members during the discussion remind that the first place was chosen by the community to build a mosque and none one asked them about the choice of place to build an income-generating building. They added that though they are poor nothing is more than their religion. Consequently, they refused it so as not be built an income-generating building in the previous place.

Communication for development is defined as the practice of communication routes, systems, and media to help people gain a full awareness of their situation and their options to change, to work towards consent, to resolve conflicts, to help people plan actions for change and sustainable development. To assist publics obtain the knowledge and skills they need to develop their condition of society, and to advance the efficiency of organizations, Fraser and Restrepo-Estrada (1998) communication for development is obligatory.

However, the project development workers said that they did not invite community members about planning and place selection. Therefore, the planned action was failed. Participatory communication plays the starring role of finding the alteration between the need of local people and the donors thought of the people have to have (Gumucio Dagron, 2001). He elucidates that society-based conversation supports to ascertain, describe and distinguish between people need and actual practices than donordriven communication needs. The finding showed that the donor wanted to build an income-generating building and then they started without local community decision. Finally, it failed.

The fourth theme was cultural and political factors affect Negede Woito community from development. The data were collected through FGD. The community members were given a bakery machine by JeCCDO, but the people who are not the member of Negede Woito community do not buy bread from them as they are out casted. One of the discussants explained that they are thought to be as not of fully humans. Specially, people who are far from Bahir Dar thought that "Negede Woito Community members are human having tails". One of the discussants said, "We are highly discriminated by both the community and government though we believe that we are the first communities who have lived in Bahir Dar at Kebele 10 around 'Shum 
Abo'(center of the town), near Lake Tana." However, the Dergue regime forced them to displace from their destination to Kebele 3 (far from the center at that time). Then after, the current government displaced them to Kebele 16 and Kebele 11 (around the periphery). Still, they are not sure what will come tomorrow, one of the discussants said,

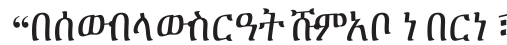

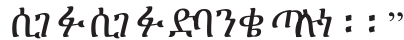

They confirmed that they do not have a guarantee whether they will be displaced or not. Their house, which is four by three care meters is a temporary destination, does not have legally certified plan. They are disturbed and believed that one day they will be displaced in the name of investment. This leads them insecure and instability life for long. Leeuwis and Hall (2010) explain unsettled social and political clashes preclude communities from working together to address mutual desires and benefits. They supplement that poor skills or capacity of actors to commence development initiatives on their own; weak capacity of homegrown organizations to respond to indigenous wants and shortage of physical and social arrangements, provision at the resident that might enrich human and social capital affects the development initiative.

In short, culturally, the communities are discriminated and that make them not to participate in selling consumable goods, like bread, 'Injera, food and drink items. Politically, different regimes have not given legal certified house plan, rather they are destined temporarily and could be displaced if the place was needed by the government any time because land owned by the government.

\section{Conclusion}

The institutional and social gaps negatively affect Negede Woito community development. Unresolved social and political conflicts have prevented Negede Woito communities from working together to address mutual desires and safety with the people. JeCCDO as development actor had poor capacity to undertake development challenges. Negede Woito did lack physical and social infrastructures that would facilitate them to heighten human and social capital. Although JeCCDO did have material support, the community members are not liberated economically, socially, politically, and psychologically. Rather, they are still discriminated, ignored and isolated from the society. The way of living is miserable. Surprisingly, more than 10 members of a family are living a four by three square care meter carton house. Development involves social learning. The community ought to employ good experiences and part these jubilations among them as a basis for enlightening deeds. Homegrown capacity building begins with the identification of indigenous capacities, worthy performs, and know-how the communities. This entails multistakeholder participation and conversation. People's empowerment lies at the core of dialogical communication method to community development where facts, acquaintance, and communication are to be deliberated strategic resources (FAO, 2010). However, the findings showed that JeCCDO did not employ a participatory communication approach during planning, implementing, and evaluating the projects at the Negede Woito community.

It is concluded that the finding was a ridiculous primary snapshot about JeCCDO's doings for Negede Woito development. It inferred that only material aid does not assure to liberate people from poverty. JeCCDO's project helped a lot to Negede Woito community, but the development efforts were not fruit full as the project did not contextualize the existing situation in the community. These imply that the project did lack clear communication strategy to approach development efforts. Lack of need assessment, lack of community participating during planning, implementing, and evaluating process made development works fail to achieve success. Eventually, it implies that poverty is not measured by only monetary ways, rather it might be psychological, spiritual, political, and cultural oriented although JeCCDO targeted on material poverty.

\section{Data availability}

All datasets analyzed and generated in this study are included in the article.

Received: 10 August 2019; Accepted: 28 February 2020; Published online: 27 March 2020

\section{References}

Acunzo M (2009) Seeking livelihood adaptation through Communication for Development. Paper presented during the 3rd International Conference

Ali C (2017) Participatory development communication in Ethiopia: a local devel opment organization in focus. PhD Dissertation. University of South Africa

Altafin I (1991) Participatory communication in social development evaluation. Community Dev J 26:312-314

Beltrán LR (2004) Communication for development in Latin America: A forty-year appraisal. Development Communicators and Publishers, Penang, Malaysia

Boafo K (1995) Utilizing development communication strategies in African societies: a critical perspective. Int Commun Gaz 35:83-95

Brett EA (1993) Voluntary agencies as development organizations: theorizing the problem of efficiency and accountability. Dev Change 24:269-304

Brown DL (1985) People-Centered Development and Participatory Research. In Alfonso Gumicio-Dragon and Thomas Tufte. (2006). Communication for Social Change; Anthology, Historical and Contemporary Readings. Communication for Social Change Consortium Inc., New Jersey

Chambers R (1997) Whose Reality Counts: Putting the First Last. Intermediate Technology Publications, London, UK

Charmaz K (2006) Constructing grounded theory. Sage, Thousand Oaks, CA

Creswell JW (2013) Qualitative inquiry and research design: Choosing among five approaches, 3rd ed. Sage, Thousand Oaks, CA

FAO (2010) Collaborative change: a communication framework for climate change adaptation and food security. FAO Communication for Sustainable Development Initiative (CSDI) (also available at http://www.fao.org/docrep/012/ i1533e/i1533e00.pdf)

Fraser C, S Restrepo-Estrada. (1998) communicating for development: human change for survival. I.B. Taurus Publishers, London and New York. (also available at http://www.cf-hst.net/unicef-temp/Doc-Repository/doc/doc478691. (PDF)

Freire P (2005) Pedagogy of the Oppressed. The Continuum International Publishing Group Inc., New York

Guba EG (Ed.) (1990) Paradigm Dialog. SAGE Publications, Newbury Park, CA

Grusky DB, Kanbur R (2006) Poverty and inequality: Studies in social inequality. Stanford University Press, Stanford

Gumucio Dagron A (2001) Making waves: stories of participatory communication for social change. The Rockefeller Foundation, New York

Handley G, Higgins K, Sharma B, Bird K, Cammack D (2009) Poverty and Poverty Reduction in Sub-Saharan Africa: An Overview of Key Issues. Overseas Development Institute, London

Hill R, Tsehaye E (2014) Ethiopia - Poverty assessment (English). World Bank Group, Washington, DC. http://documents.worldbank.org/curated/en/ 131011468247457565/Ethiopia-Poverty-assessment

Hornik R (1988) Development communication: information, agriculture, and nutrition in the Third World. Longman Publishing Group, New York

Jeff H (2011) Faith-Inspired Development Work and the Millennium Development Goals: Past Progress and Future Opportunities. George Town University, Berkeley Center

Kombo D (2006) Proposal and Thesis Writing: Nairobi: Paulines Publications

Leeuwis C, A Hall (2010) Facing the challenges of climate change and food security: the role of research, extension and communication institutions. Assignment commissioned by FAO Research and Extension Branch (available at http://edepot.wur.nl/176533)

Lewis D, Kanji N (2009) Non-Governmental Organizations and Development. Routledge, Abingdon, UK

Lipton M, Ravallion M (1993) Poverty and Policy: Poverty and human resource. The world Bank: Policy Research Dissemination Center

Mefalopolus P (2008) Development communication sourcebook: broadening the boundaries of communication. World Bank, Washington DC. (also 
available at http://siteresources.worldbank.org/EXTDEVCOMMENG/Resources/ DevelopmentCommSourcebook.pdf)

Mefalopulus P, Tufte T (2009) Participatory Communication; A Practical Guide. World Bank, Washington DC

Mefalopulus P (2003) Theory and practice of participatory communication: the case of the FAO project "Communication for Development in Southern Africa". The University of Texas at Austin, Doctor of Philosophy

Melkote SR (1991) Communication for development in the Third World: theory and practice. Sage Publications, New Delhi

Mendes P, Binns F (2013) The integration of community development values, skills and strategies within rural social work practice in Victoria, Australia. Community Dev J 48:605-622

Obeng-Quaidoo (1986) A proposal for new communication research methodologies in Africa. AfricaMediaReview 1(1):89-99. Available: http://www.sanweb. lib.msu.edu/.../African\%20Journals/.../africa\%20media

Ritchie J, Lewis J (2003) Qualitative research practice: a guide for social science students and researchers. SAGE, London

Rogers E (1962) Diffusion of innovations. The Free Press, New York

Sackey E (2014) The Role of Grassroots Communication in NGO Development Projects in Africa: A Case Study of ABT Associates in the US Government's Indoor Residual Spraying Program in Tamale, Northern Ghana. (Electronic Thesis or Dissertation). Retrieved from https://etd.ohiolink.edu/

Servaes J (1996) Participatory communication: research from a Freirean. Afr Media Rev 10(1):73-91

Snape D \& Spencer L (2003) The foundations of qualitative research. In: Ritchie J, Lewis J (ed.) Qualitative research practice: a guide for social science students and researchers, SAGE, London, pp 1-23

Vakil AC (1997) Confronting the classification problem: Toward taxonomy of NGOs. World Dev 25(12):2057-2070

White SA (1994) The concept of participation: transforming rhetoric to reality. Sage Publications, Thousand Oaks

\section{Acknowledgements}

I would like to thank Mr. Mastewal M. Alemayehu for his contribution by proofreading this paper entirely.

\section{Competing interests}

The author declares no competing interests.

\section{Additional information}

Correspondence and requests for materials should be addressed to N.B.G.

Reprints and permission information is available at http://www.nature.com/reprints

Publisher's note Springer Nature remains neutral with regard to jurisdictional claims in published maps and institutional affiliations.

\section{(c) (i)}

Open Access This article is licensed under a Creative Commons Attribution 4.0 International License, which permits use, sharing, adaptation, distribution and reproduction in any medium or format, as long as you give appropriate credit to the original author(s) and the source, provide a link to the Creative Commons license, and indicate if changes were made. The images or other third party material in this article are included in the article's Creative Commons license, unless indicated otherwise in a credit line to the material. If material is not included in the article's Creative Commons license and your intended use is not permitted by statutory regulation or exceeds the permitted use, you will need to obtain permission directly from the copyright holder. To view a copy of this license, visit http://creativecommons.org/ licenses/by/4.0/

(C) The Author(s) 2020 